\title{
The Theory of Planned Behavior and Financial Literacy to Analyze Intention in Mutual Fund Product Investment
}

\author{
Safira Amalia Hapsari ${ }^{1, *}$ \\ ${ }^{1}$ Institut Teknologi Bandung \\ ${ }^{*}$ Corresponding author. Email: sframalia@gmail.com
}

\begin{abstract}
Mutual funds in Indonesia face rapid growth in total asset under management (AUM), the number of products, and the number of investors. The growth is supported by digital innovation, making people comfortable accessing information and doing mutual fund transactions using the internet. Besides the appearance of the marketplace that offers mutual fund products, people get convenience in terms of time and cost. This study aims to determine what factor influences intention on investing in mutual fund products by using an approach from the theory of planned behavior. Theory of planned behavior can be used to predict and understand factors that determine particular behavior. The theory identified that attitude, subjective norms, and perceived control behavior would collectively form a behavioral intention. In this study, the variables used consist of attitude, subjective norm, perceived control behavior, and another variable added to measure investment intention, which is financial literacy. The analysis technique in this study is multiple linear regression. The sampling method is using nonprobability sampling, which involves Indonesian mutual fund investors. This study indicates that, in general, the attitude had a positive effect and strongest predictor on the intention to invest in mutual funds product.
\end{abstract}

Keywords: The Theory of Planned Behavior, Financial Literacy, Intention, Mutual Fund, Investment.

\section{INTRODUCTION}

Investment is any vehicle into which funds can be placed with the expectation that it will generate positive income and/or preserve or increase its value [1]. Investors place their funds for getting a return in investing, and the amount is under risk borne. The existence of capital markets encourages an efficient fund allocation since those who have excess funds (investors) can choose an optimal investment alternative [2]. Financial instruments in the capital market can be chosen, such as stocks, bonds, right, warrants, derivatives, and mutual funds.

In Indonesia, mutual funds started to become investor's choice to place their money. It can be seen from the growth of total assets under management (AUM), number of products, and number of investors. At the end of 2018, total assets under management reached 507 trillion rupiahs, $11 \%$ higher than December 2017. In terms of the number of investors, more than 140 percent increase was recorded in the past two years reached
822,221 investors in July 2018, compared with August 2016 with total investors 340,869 (KSEI). While total mutual fund products reached 2040 products, increased 40\% compared with 2016.

The development of mutual funds is supported by digital innovation, which made people access information easily and did mutual fund transactions using the internet. The appearance of supermarket fund and the marketplace that offer mutual fund products also helped increase investors' number. With those facilities, people get convenience in terms of time and cost.

There are various aspects of the investment decisionmaking process. Based on conventional financial theory, such as Efficient Market Hypothesis, it assumed that investors with their reason always optimize the expected values; hence their behavior does not include psychological factors [3]. Therefore, behavioral finance appeared as an alternative to explore investor behavior 
since it explores the role of psychology and other social aspects in investors' decisions [4].

The Theory of Planned Behavior (TPB) provides a robust theoretical model to predict behavioral intentions in investment intention. Attitude, subjective norm, and perceived control behavior are the significant three essential elements of TPB in explaining behavior that has been claimed in multiple studies included [5].

Besides the role of psychology, financial literacy helps people process financial information and decide about personal finance. People who know about financial literacy will understand the risk and return associated with the financial product and can make effective use of a financial product by choosing the product that best suited them.

This study assesses whether psychological factors (attitude, subjective norm, and perceived control behavior) and knowledge (financial literacy) can significantly develop mutual fund investment intention.

\subsection{Theory of planned behavior}

Theory of Planned Behavior from [6] is an extended work of Ajzen and Fishbein, who proposed the Theory of Reasoned Action (TRA). Theory of Planned Behavior provides a theoretical model to study the relationship's constructs among three independent factors that shape an individual's intention: attitude, subjective norm, and perceived behavioral control. According to [6], the more favorable the attitude and subjective norm concerning behavior, the greater the perceived behavioral control, the stronger should be an individual's intention to perform the behavior under consideration.

\subsection{Intention}

Intention indicates the extent to which someone is willing to attempt and the amount of effort they are planning to perform particular behavior [7]. It represents a person's motivation in the sense of people's conscious plan or decision to perform particular behavior [8]. Several studies have used investment intention as the dependent variable to measure intention to invest [9-12].

\subsection{Attitude}

Reference [7] defines attitude as the degree to which a person has a favorable or unfavorable evaluation of performing a specific behavior. The evaluation consists of assessing two components, the importance or value of the action and pleasure from the action. Generally, the more positive attitude towards certain behavior is, the stronger should be the intention to perform the behavior [13].

From previous research, [14-16] found that investors had a good and positive attitude towards the investment in mutual funds. A specific attitude such as investor's awareness and confidence, investment horizon, high return, and safety become a consideration when choosing mutual fund.

Based on the above discussion and past literature, this study postulates the following hypothesis.

H1: Attitude has a significant positive impact on mutual fund investment.

\subsection{Subjective norm}

Subjective norm refers to the perceived influence that these significant others have on a person's intentions and behavior [17]. Subjective norms become the function of belief about the expectation of important referent, and personal motivation of complying with these. Subjective norms become a measurement of the social influences of social peers such as family and friends on a person's behavior or activity.

References $[9,10,18]$ found that subjective norms had a positive correlation with the intention to invest. In comparison, [11] found that subjective norms positively impacted intention to use internet stock trading. Social circles such as family and friends are influential in shaping someone's attitude, as well as the other way around. The more popular financial investment product in peer's group, the higher the likelihood of a person's buying or investing in financial products. Peers and important referents were essential in investment decision-making. Investors also seemed to look for other's acceptance for decisions, although the investment is risky.

While [19] found that subjective norm is not positively associated with intention to invest of investors in Spanish Stock Exchange. It could be happened since financial transactions might be very private for many people and became less influenced by norms. Some people also might motivate other people depending on their perceived competence in the stock market.

Based on the above discussion and past literature, this study postulates the following hypothesis.

$\mathrm{H} 2$ : Subjective norm has a significant positive impact on mutual fund investment.

\subsection{Perceived control behavior}

Perceived behavioral control refers to perceived ease or difficulty of performing the behavior, and it is assumed to reflect past experience and anticipate impediments and obstacles [6]. Intention increases when individuals perceive they have more resources and confidence [20, 21].

From previous studies, $[9,10,22]$ found that perceived behavior control had a positive correlation with 
the intention for investing. Awareness, experience, and resources affect people for the investment decisionmaking process. Investors who engaged in investment activities longer became more inclined and had a better experience so that it would lead to positive behavioral intention.

While [23, 24] found that perceived control behavior is insignificant to investment intention. Self-efficacy and personal decision are not significant to investment intention.

Based on the above discussion and past literature, this study postulates the following hypothesis.

H3: Perceived control behavior has a significant positive impact on mutual fund investment.

\subsection{Financial literacy}

Reference [25] defined financial literacy as a person's ability to understand and use financial concepts. Financial literacy helps individuals improve their understanding of financial matters, which enables them to process financial information and make informed decisions about personal finance, such as savings, borrowing, investment, retirement planning, etc. [26].

In the relation between financial literacy and investment intention, [27-29] found that financial literacy had a significant positive impact on investment intention. Besides that, the level of financial literacy also made different preferences. People with low financial literacy preferred to invest in traditional and safe financial products and did not invest in riskier financial products and gave higher returns.

While [30] found that level of financial literacy among retail customers did not significantly affect the intention to invest in medium/high-risk financial investment. Lack of a statistically significant relationship between the financial education level of retail customers and investment intentions could be explained by a high financial literacy level.

H4: Financial literacy has a significant positive impact on mutual fund investment.

\section{METHODS}

\subsection{Data collection}

The questionnaire was administered to gather data from mutual fund investors in Indonesia. The research data were collected from a sample of 141 individual investors who have mutual fund products.

\subsection{Questionnaire development and measurement}

The questionnaire comprised of three significant aspects: (1) Demographics factors, (2) Psychological factors (Theory of Planned Behavior), and (3) Financial literacy.

The questionnaires for measuring psychological factors were designed to use the five-point Likert Scale that describes each statement. Questionnaires are adopted from $[9,22]$.

There were 15 questions adopted from [31] for measuring financial literacy. The questions are divided into basic financial literacy and advanced financial literacy. Each question has some weight with others.

In this study, reliability and validity test were established, and all questionnaires were passed the test. Table 1 shows the reliability test result.

Table 1. The reability test result

\begin{tabular}{|l|l|l|}
\hline \multicolumn{1}{|c|}{ Variable } & \multicolumn{1}{|c|}{ Cronbach alpha } & \multicolumn{1}{|c|}{ Status } \\
\hline Attitude & 0.804 & Reliable \\
\hline Subjective norm & 0.774 & Reliable \\
\hline Perceived control behavior & 0.66 & Reliable \\
& & \\
\hline Financial literacy & 0.659 & Reliable \\
\hline Investment intention & 0.823 & Reliable \\
\hline
\end{tabular}

\subsection{Data analysis}

The methodology that was used in this research is Multiple Linear Regression (MLR). The general purpose of MLR is to predicting dependent variables from several independent variables in the level of measurement and type of variables [32]. The dependent variable in this research is mutual fund investment intention. Independent variables in this research are attitude, subjective norm, perceived control behavior, and financial literacy. The regression equation that used is (1).

$\mathrm{Y}=\mathrm{a}+\mathrm{b} 1 \cdot \mathrm{ATT}+\mathrm{b} 2 \cdot \mathrm{SN}+\mathrm{b} 3 \cdot \mathrm{PBC}+\mathrm{b} 4 \cdot \mathrm{FL}+\mathrm{e}$

Where:

- $\quad \mathrm{y}=$ Mutual fund investment Intention

- $\mathrm{a}=$ Constants

- $\quad \mathrm{ATT}=$ Attitude

- $\mathrm{SN}=$ Subjective Norm

- $\quad \mathrm{PBC}=$ Perceived Behavior Control

- $\quad \mathrm{FL}=$ Financial Literacy

- $\mathrm{e}=$ error 


\section{RESULTS AND DISCUSSION}

\subsection{Results}

Based on Table 2, the multiple regression analysis models were significant $(\mathrm{p}=0.00)$ with an F-value of 17.939. The adjusted $\mathrm{R}$ square score is 0.346 , which indicates $34.6 \%$ of mutual fund investment intention can be explained by independent variables. In contrast, the remaining is explained by other variables.

Table 2. Multiple regression analysis result

\begin{tabular}{|l|l|}
\hline \multicolumn{1}{|c|}{ Variable } & \multicolumn{1}{c|}{ Unstandardized $\beta$} \\
\hline (Constant) & 3.016 \\
\hline Attitude & $0.396^{*}$ \\
\hline Subjective norm & 0.039 \\
\hline Perceived control behavior & 0.114 \\
\hline Financial literacy & 0.082 \\
\hline $\mathrm{F}$ & 17.939 \\
\hline $\mathrm{R}^{\mathbf{2}}$ & 0.367 \\
\hline Adjusted $\mathrm{R}^{\mathbf{2}}$ & 0.346 \\
\hline Notes: ${ }^{*} \mathrm{p}<0.05$ & \\
\hline
\end{tabular}

Significant factors that describe the respondent's investment intention is the attitude with an unstandardized coefficient B is 0.396 . It means that there is a positive relationship to investment intention. Other independent variables such as subjective norm, perceived control behavior, and financial literacy is not significantly related to investment.

After removing the insignificant variables, the equation are shows in (2).

$$
\mathrm{Y}=3.016+0.396 \mathrm{ATT}+\mathrm{e}
$$

Where:

- $Y=$ mutual fund investment intention

- $\quad \mathrm{ATT}=$ attitude toward mutual fund investment

- $\mathrm{e}=$ error

\subsection{Discussion}

In this research, variables used for determining mutual fund investment intention were attitude, subjective norm, perceived control behavior, and financial literacy. The result shows that attitude is the only variable that significantly impacts investment intention, determined by sig. the value was below 0.05 .

Attitude has a significant positive impact on mutual fund investment. The result is similar to [11] that attitude influences intention for doing online trading, [9, 19] findings that attitude has a significant positive impact on investment intention. Attitude also becomes the most significant predictor to invest. It indicates that decision to invest in a mutual fund is based on individual evaluation and is determined by themselves. A favorable, confident, secured attitude was able to increase intention to invest in the mutual fund.
Another variable, subjective norm, is not positively significant to investment intention. The result is similar to [19], which states that subjective norm is not positively associated with investment intention. Reference [19] suggested that some people look at the financial transaction as private matters, so possibly people could be less influenced by norms. From the research findings, although mutual fund investment is considered a wise idea by family members and essential relatives, but the number of friends or relatives that invested in the mutual fund is still low. It can be seen from respondents' answers that state disagreement to indifference related to a mutual fund that a friend owns. So, people could be less influenced by the subjective norm.

While variable perceived control behavior is not positively significant to investment intention. The result is similar to findings from $[12,23,24]$. It means that the assumption of easiness or difficulties for investing in a mutual fund did not affect the intention to invest. Investor's control over the decision does not influence to have stronger investment intention.

The last variable, financial literacy, is not positively significant to investment intention. The result is similar to the finding from [30]. It explained that intention to invest is not affected by financial literacy. A high level of understanding of financial literacy among mutual fund investors can become the reason. The findings show that, on average, the respondents who already have mutual fund products can answer 11 questions correctly out of 15 questions. So financial literacy may not be a good predictor of investors' intention to invest in financial investment products.

\section{CONCLUSIONS}

The study observed factors in the theory of planned behavior such as attitude, subjective norm, and perceived behavior with additional variable financial literacy to measure mutual fund investment intention. The literature of previous studies was reviewed related to the use of the theory of planned behavior towards financial investment intention.

The result outlines that the significant factor related to investment intention is attitude. It is positively correlated between the independent variable and investment intention. It can be concluded that decision to invest in a mutual fund is based on individual evaluation and value from the investment itself. In this research, the value that is believed by investors towards mutual funds is favorable, secured, and wise. While other variables, subjective norm, perceived control behavior, and financial literacy, are insignificant to mutual fund investment intention. It means that social peers, an individual's control and skills, and knowledge about a financial concept do not affect investment intention. 
This study provides the importance of attitude to increase the investment intention of mutual fund investors. By creating awareness and giving more product knowledge will increase evaluation towards mutual fund products and lead to higher intention to invest in the mutual fund.

\section{REFERENCES}

[1] M. D. Gitman, L. J., \& Joehnk, Fundamentos de inversiones. Pearson educación, 2005.

[2] M. Alteza, "Efek hari perdagangan terhadap return saham : suatu telaah atas anomali pasar efisien," J. ilmu Manaj., 2007.

[3] K. C. Phan and J. Zhou, "Market efficiency in emerging stock markets: A case study of the Vietnamese stock market," IOSR J. Bus. Manag., 2014.

[4] D. Kourtidis, Ž. Šević, and P. Chatzoglou, "Investors' trading activity: A behavioural perspective and empirical results," J. Socio. Econ., 2011.

[5] L. Sommer, "The theory of planned behaviour and the impact of past behaviour," Int. Bus. Econ. Res. J., 2011.

[6] Ajzen, "The theory of planned behavior organizational behavior and human decision processes," Organ. Behav. Hum. Decis. Process., 1991.

[7] Ajzen, Attitudes, Personality, and Behavior. Chicago, IL: Dorsey Press, 1988.

[8] M. Conner and C. J. Armitage, "Extending the theory of planned behavior: A review and avenues for further research," Journal of Applied Social Psychology. 1998.

[9] R. K. Raut, N. Das, and R. Kumar, "Extending the theory of planned behaviour: Impact of past behavioural biases on the investment decision of Indian investors," Asian J. Bus. Account., 2018.

[10] N. Schmidt, "What drives investments into mutual funds? Applying the theory of planned behaviour to individuals' willingness and intention to purchase mutual funds," Retail Invest. Conf., 2010.

[11] M. Gopi and T. Ramayah, "Applicability of theory of planned behavior in predicting intention to trade online: Some evidence from a developing country," Int. J. Emerg. Mark., 2007.

[12] D. dan W. A. W. G. C. D.A.I, "Impact of psychology on behavioral intention in investing in capital markets: A survey of Colombo Stock Exchange," Int. J. Account. Bus. Financ., 2015.
[13]C. J. Armitage and M. Connor, "Efficacy of the theory of planned behavior: A meta-analysis," Br. J. Soc. Psychol., vol. 40, no. 4, pp. 471-499, 2001.

[14]R. Amsaveni and S. Ranjini, "Investor's attitude towards mutual fund in Coimbatore city," Int. J. Adv. Sci. Res. Manag., vol. 3, no. 5, pp. 135-139, 2018.

[15]K. P. Sindhu and S. Rajitha Kumar, "A study on influence of investment specific attitudes of investors on investment decisions.," Indian J. Commer. Manag. Stud., 2013.

[16]P. Subramanya and T. Murthy, "Investors attitude towards mutual funds (special reference to Chikkamagalore District, Karnataka State, India)," Int. J. Manag. Busniess Stud., vol. 3, no. 1, 2013.

[17] Ajzen and B. L. Driver, "Application of the theory of planned behavior to leisure choice," J. Leis. Res., 1992.

[18] P. Alleyne and T. Broome, "Using the theory of planned behaviour and risk propensity to measure investment intentions among future investors," J. East. Caribb. Stud., vol. 36, no. 1, pp. 1-21, 2011.

[19] D. Pascual-Ezama, B. Scandroglio, and B. G. G. de Lian\&tild;o, "Can we predict individual investors' behavior in stock markets? A psychological approach," Univ. Psychol., 2014.

[20]Ajzen, "From intentions to actions: A theory of planned behavior," in Action Control, 1985.

[21]Y. Lee and K. A. Kozar, "Investigating factors affecting the adoption of anti-spyware systems," Communications of the ACM. 2005.

[22] M. H. Warsame and E. M. Ireri, "Does the Theory of Planned Behaviour (TPB) matter in Sukuk investment decisions?," J. Behav. Exp. Financ., 2016.

[23] C. M. Sondari and R. Sudarsono, "Using theory of planned behavior in predicting intention to invest : Case of Indonesia," Int. Acad. Res. J. Bus. Technol., 2015.

[24] Y. Ibrahim and I. Arshad, "Examining the impact of product involvement, subjective norm and perceived behavioral control on investment intentions of individual investors in Pakistan," Invest. Manag. Financ. Innov., 2017.

[25] L. J. Servon and R. Kaestner, "Consumer financial literacy and the impact of online banking on the financial behavior of lower-income bank customers,” J. Consum. Aff., 2008. 
[26] P. Bhushan, "Relationship between financial literacy and investment behavior of salaried individuals," J. Bus. Manag. Soc. Sci. Res., 2014.

[27] M. N. Sadiq and R. A. A. Khan, "Financial literacy, risk perception and investment intention among youth in Pakistan," nternational J. Manag. Sci. Bus. Res., vol. 7, no. 5, pp. 85-93, 2018.

[28] P. Bushan and Y. Medury, "Financial literacy and its determinants,” Int. J. Eng. Bus. Enterp. Appl., vol. 4, no. 2, pp. 155-160, 2013.

[29] M. C. J. van Rooij, A. Lusardi, and R. J. M. Alessie, "Financial literacy, retirement planning and household wealth,” Econ. J., 2012.
[30]D. Cucinelli, G. Gandolfi, and M.-G. Soana, "Customer and advisor financial decisions: the theory of planned behavior perspective," Int. J. Bus. Soc. Sci., 2016.

[31]M. Van Rooij, A. Lusardi, and R. J. M. Alessie, "Financial literacy and stock market participation (No. 2007/27)," Cent. Financ. Stud., 2007.

[32] N. L. Leech, K. C. Barrett, and G. A. Morgan, SPSS for Intermediate Statistics: Use and Interpretation, 2nd ed. New Jersey: Lawrence Erlbaum Associates, 2005 . 